J. D. Hooker has already accomplished, and by which his high scientific position has been earned, must needs be either too technical or too long for a sketch like this. Moreover, the Atlantic is no longer what it once was, when a judgment wafted across it either way was invested with somewhat of the character of the verdict of posterity. And the close relations for forty years of the present writer with the Hookers, father and son, disqualify him for the office of judge. Let that duty devolve upon our sucm cessors.

The knowledge and experience of most of our eminent botanists have been gained, and their work mainly done, in the herbarium and botanic garden. No living botanist that we know of has shared Sir J. D. Hooker's opportunities of studying in place the living vegetation of so many parts of the world; these include, besides those already mentioned as places visited during his Antarctic voyage, the southern shores of Europe, North Africa, Palestine, and India to the Chinese borders. When we have welcomed him to New England, as we hope to do before these lines are in print, and when he has traversed our continent from the Atlantic to the Pacific, it may confidently be affirmed that he has seen far more Borán than ever fell to the lot of any other of his craft.

Sir J. D. Hooker was elected President of the Royal Society in 1873 , an office which he still holds.

$$
\text { May, } 1877
$$

$$
\text { ASA GRAY }
$$

\section{NOTES ON THE BOTANY OF THE ROCKY MOUNTAINS}

[The contemplated visit to the United States of America alluded to in the preceding article has now been accomplished, and Sir Joseph Hooker has favoured us with the notes of his journey following.]

[N company with Dr. Asa Gray, Professor of Botany of 1 Harvard University, Cambridge, U.S., I availed myself of an oft-repeated invitation to us both from Dr. Hayden, the distinguished chief of the Topographical and Geological Survey of the United States Territories, to join the Survey in Colorado and Utah; this we did with the view of instituting a comparison between the floras of these central and elevated territories and those of other parts of the continent, and thus obtaining some insight into the origin and distribution of the North American flora. In order to comprehend the importance of Colorado and Utah as the basis for such investigations, I should state that they occupy a very central position in the continent, and include a section of the Rocky Mountains about 300 miles long and about as broad, namely, from N. lat. $37^{\circ}$ to $41^{\circ}$, and from W. long. $105^{\circ}$ to $112^{\circ}$.

The mountain region thus limited consists of extensive and often level floored valleys, sometimes many miles broad, and elevated 4,000 to 5,000 feet above the sea, called "parks" in local topography, which are interposed between innumerable rocky mountain ridges of very various geological age and formation, which often reach 12,000 feet, and sometimes I 4,000 feet elevation, the maximum being under 14,500 .

Those of the so-called parks which are watered by rivers that flow to the east are continuous with the prairies that lie along the eastern flanks of the Rocky Mountains ; those watered by rivers that flow to the west are continuous with the so-called desert or salt regions that lie along the western flanks of the range; but the divides between the head waters of the streams that flow either way are often low, and the botanical features of the east and west may hence meet and mix in one park.

Such a section of the Rocky Mountains must hence contain representatives of three very distinct American floras, each characteristic of immense areas of the continent. There are two temperate and two cold or mountain floras, viz. : (I) a prairie flora derived from the eastward ; (2) a so-called cesert and saline flora derived from the west; (3) a sub-alpine; and (4) an alpine flora; the two latter of widely different origin, and in one sense proper to the Rocky Mountain ranges.

The principal American regions with which the comparison will have first to be instituted are four. Two of these are in a broad sense humid; one, that of the Atlantic coast, and which extends thence west to the Mississippi river, including the forested shores of that river's western affluents; the other that of the Pacific side, from the Sierra Nevada to the western ocean : and two in!and, that of the northern part of the continent extending to the Polar regions, and that of the southern part extending through New Mexico to the Cordillerd of Mexico proper.

The first and second (Atlantic plus Mississippi and the Pacific) regions are traversed by meridional chains of mountains approximately parallei to the Rocky Mountains ; namely, on the Atlantic side by the various systems often included under the general term Appalachian, which exterd from Maine to Georgia, and on the Pacific side by the Sierra Nevada, which bounds California on the east. The third and 'ourth of the regions present a continuation of the Rocky Mo nntains of Colorado and Utah, flanked for a certain distance by an eastern prairie flora extending from the British possessions to Texas, and a western desert or saline flora, extending from the Snake River to Arizona and Mexico. Thus the Colorado and Utah floras might be expected to contain representatives of all the various vegetations of North America except the small tropical region of Florida, which is confined to the extreme south-east of the Continent.

The most singular botanical feature of North America is unquestionably the marked contrast between its two humid floras, namely, those of the Atlantic plus Mississippi, and the Pacific one ; this has been ably illustrated and discussed by Dr. Gray in various communications to the American Academy of Sciences, and elsewhere, and he has further largely traced the peculiarities of each to their source, thus laying the toundations for all future researches into the botanical geography of North America; but the relations of the dry intermediate $t \mathrm{e}-$ gion either to these or to the floras of other countrie had not been similarly treated, and this we hope that we have now materials for discussing.

Our course and direction in America was directly westward to Colorado, where we followed the eastern flanks of the Rocky Mountains for about 300 miles, that is from Denver in the north, to near the borders of New Mexico, ascending the highest northern and southern peaks, and visiting several intermediate parks and valleys, watered by tributaries of the Arkansas, Platte, Colorado, and Rio Grande. From Denver we proceeded north 
to Cheyenne in Wyoming, and thence westward by the Central Pacific Railway, across the range to Ogden, and the Great Salt Lake in Utah, which lies on the base of the Wahsatch Mountains, themselves the western escarpment of the Rocky Mountains proper in that latitude. After ascending these we proceeded westward by rail through Utah, to Nevada, thus crossing the great dry region that intervenes between the Rocky Mountains and the Sierra Nevada, which is variously known as the Desert, Salt, or Sink region of North America, in accordance with the prevailing features of its several parts. It is elevated 3,000 to 4,000 feet; and traversed by numerous short meridional mountain-ridges, often reaching 8,000 feet, and rarely 10,000 feet elevation ; unlike the Rocky Mountains or over the Sierra Nevada, these present no forest-clad slopes, or even a sub-Alpine flora.

From Reno, at the western base of the Sierra Nevada, we proceeded south by Carson City, flanking the Sierra for some sixty miles to Silver Mountain, when we struck westwards, ascending the Sierra, which was crossed obliquely into the Pacific slope. There we visited three groves of the 'Big Trees' (Sequoia gigantea) at the headwaters of Stanislaus and Tuolome Rivers, and the singular Yosemite Valley, whence we descended into the great valley of California, and made for San Francisco.

From the latter place we made excursions first to the old Spanish settlement of Monterey, which is classical ground for the botanist, as being the scene of Menzies' labours during the voyage of our countryman, Capt. Vancouver, in 1798 (whose surveys are held in the highest estimation by Prof. Davidson and the officers of the Coast Survey of the United States), whom he accompanied as botanist. Then we went northwards along the coast range to Russian River to visit the forests of Red-wood (Sequoia sempervirens), the only living congener of the Big Trees, and almost their rival in bulk and stature. Then to Sacramento, and up the valley of that name for 150 miles to Mount Shasta, a noble forest-clad volcanic cone about 14,400 feet in elevation. Returning thence to Sacramento we took the Union Pacific Railway east. wards, and from the highest station visited Mount Stanford, on the crest of the Sierra Nevada, and Lake Taho, which occupies a basin in the mountains at about 7,000 feet elevation, and with which we finished our western journeyings.

In California the Coniferæ were a principal study, with a view of unravelling their tangled synonymy and tracing the variations and distribution of these ill-understood trees, which attain their maximum development in number of species and in stature on the Pacific slope of the American continent.

The net result of our joint investigation and of Dr. Gray's previous intimate knowledge of the elements of the American flora is, that the vegetation of the middle latitudes of the continent resolves itself into three principal meridional floras, incomparably more diverse than those presented by any similar meridians in the old world, being, in fact, as far as the trees, shrubs, and many genera of herbaceous plants are concerned, absolutely distinct. These are the two humid and the dry intermediate regions above indicated.
Each of these, again, is subdivisible into three, as follows :-

I. The Atlantic slope plus Mississippi region, sub. divisible into $(\alpha)$ an Atlantic, $(\beta)$ a Mississippi valley, and $(\gamma)$ an interposed mountain region with a temperate and sub-alpine flora.

2. The Pacific slope, subdivisible into $(a)$ a very humid cool forest-clad coast range; $(\beta)$ the great hot, drier Californian valley formed by the San Juan river flowing to the north, and the Sacramento river flowing to the south, both into the Bay of San Francisco; and $(\gamma)$ the Sierra Nevada flora, temperate, sub-alpine, and alpine.

3. The Rocky Mountain region (in its widest sense extending from the Mississippi beyond its forest region to the Sierra Nevada), subdivisible into $(\alpha)$ a prairie flora; $(\beta)$ a desert or saline flora ; $(\gamma)$ a Rocky Mountain proper flora, temperate, sub-alpine, and alpine.

As above stated, the difference between the floras of the first and second of these regions, is specifically, and to a great extent generically absolute; not a pine or oak, maple, elm, plane, or birch of Eastern America extends to Western, and genera of thirty to fifty species are confined to each. The Rocky Mountain region again, though abundantly distinct from both, has a few elements of the eastern region and still more of the western.

Many interesting facts connected with the origin and distribution of American plants and the introduction of various types into the three regions, presented themselves to our observation or our minds during our wanderings ; many of these are suggestive of comparative study with the admirable results of Heer's and Lesquereux's investigations into the pliocene and miocene plants of the north temperate ard frigid zones, and which had already engaged Dr. Gray's attention, as may be found in his various publications. No less interesting are the traces of the influence of a glacial and a warmer period in directing the course of migration of Arctic forms southward, and Mexican forms northward in the continent, and of the effects of the great body of water that occupied the whole saline region during (as it would appear) a glacial period.

Lastly, curious information was obtained respecting the ages of not only the big trees of California, but of equally aged pines and junipers, which are proofs of that duration of existing conditions of climate for which evidence has hitherto been sought rather amongst fossil than amongst living organisms.

I need hardly add that the part 1 played in the above sketched journey was wholly subordinate to Dr. Gray's, who had previously visited both the Rocky Mountains and California, though not with the same object. But for his unflinching determination that nothing should escape my notice which his knowledge and observant powers could supply, and Dr. Hayden's active co-operation, my own labours would have been of little avail.

Moreover, throughout the expedition we experienced great hospitality, and enjoyed unusual facilities, not only from the staff of the Geological Survey, but from the railway authorities, who franked us across the continent, and on all the branch lines which we traversed.

J. D. HOOKER: 